\title{
FUTURES PRICE AND TRADING VOLUME: EVIDENCE FROM MALAYSIA
}

\author{
BAKRI ABDUL KARIM \\ Faculty of Economics and Business \\ Universiti Malaysia Sarawak \\ ZULKEFLY ABDUL KARIM \\ Faculty of Economics and Management \\ Universiti Kebangsaan Malaysia
}

\begin{abstract}
This paper examines the long-and short-run dynamic causality between the futures price and trading volume in the Malaysian equity market. The data of futures price, trading volume and spot price are in daily frequency, spanning from 2006 to 2009. By using ARDL cointegration and VECM causality tests, the findings revealed the existence of long-run relationship between futures price, volume and spot prices. In addition, there exists a short-run bidirectional causality relationship running between futures return-trading volume and futures return-spot return. Thus, the stock index futures market in Malaysia is not informational efficient.
\end{abstract}

Keywords: Futures price, trading volume, Malaysia.

\section{Introduction}

The relationship between price-volume in financial markets has been studied extensively by academicians, practitioners and policy makers for many years. Copeland (1976) explained the stock price-volume relation with information flows and the existence of market institutions. In addition, Chordia and Swaminathan (2000) documented that the cross-autocorrelation patterns in shorthorizon stock returns have differential trading volume speed of adjustment to information, which is an important source. Furthermore, Chordia and Swaminathan (2000) noted that low-volume stocks adjusting more slowly than high-volume stocks to market-wide information shocks. Karpoff (1987) noted that the understanding of the relationship between price-volume is important to help discriminate between competing theories on how information has disseminated in financial markets. Financial economists and practitioners have recognized that trading volume may provide important information on security pricing. In addition, the pricevolume relationship is also important for event studies from which to draw inferences. The return-volume relation also is critical to the debate over the empirical distribution of speculative prices and provides significant implications for studies in the futures markets. Blume, Easley and O'hara (1994) found that traders can profit from using volume information in addition to historical price information in making projections 
about future price changes. Many researchers have tried to develop theoretical models that assume the price - volume relation based on information flows and the existence of market institutions. Some theoretical explanations for these relations are the sequential arrival of information developed by Copeland (1976), the mixture of distribution hypothesis developed by Clark (1973) and Epps and Epps (1976), tax and non-tax related motive for trading developed by Lakonishok and Smidt (1989) (see Tauchen and Pitts, 1983; and Karpoff, 1987 for an excellent literature review on this).

Unlike most of the above studies that employed conventional stock indices in exploring the price-volume relationship, this study employs futures market index. Using the futures market, to the best of our knowledge, the research goes clearly beyond the existing literature on the subject matter in Malaysia. Futures market is one of the popular trading markets nowadays. A stock index futures contract is an exchange traded of derivative equity that its underlying asset is the basket of common stocks that constructs the index. Since the amount of money involved in stock index futures trading is large, the institutional investors are the main players in the markets. Today, stock index futures are very actively traded on several exchanges in various countries. Trading in the contracts has increased tremendously to become second only to interest rate futures contracts (Bacha, 2006). There is a positive signal and early signs of validation for the globalisation path that Malaysia has chosen for the derivatives industry. Overall, foreign participation increased from $21.2 \%$ in 2009 to 27.3\% in 2010 (Bursa Malaysia Derivatives Berhad, 2010). Using daily data from the cotton futures market, Clark (1973) provides evidence of a positive correlation between the square of price change and aggregated trading volume. In a more recent study, Long (2007) found that the price-volume relationship found in the equity markets also exists within the option markets and there are significantly positive price volume correlation between the absolute value of call price changes and volume. However, Bessembinder and Segun (1992) found evidence that linking volatility to total volume does not extract all information in financial futures markets. When volume was partitioned into expected and unexpected components, they found that unexpected volume shocks have a larger effect on volatility and the relation was asymmetric.

The purpose of this paper is to extend this line of research to the case of futures markets. In particular, the study aims to examine empirically the relationship between index futures price and trading volume in Malaysia. We hope to shed some light on the issue since the study goes clearly beyond the existing literature on the subject matter in Malaysia. However, focusing on these two variables in a bivariate setting may not be satisfactory since they may driven by common factors. In other words, the omission of important variables may end up with spurious results. It is believed that trading activity in equity futures markets can lead to excess volatility in spot equity markets (Bessembinder \& Segun, 1992). Thus, we also include spot prices as a control variable to arrive at richer findings. The results of the study may have important implications regarding market efficiency and the effects of different market characteristics on the stock price/volume relation.

The rest of this paper is structured as follows. Section 2 provides some literature review. The empirical framework and description of the data are discussed in section 3 . Section 4 provides the empirical results and discussion. Finally, section 5 summarizes and concludes. 


\section{Literature Review}

Since 1959, the relationship between stock prices and trading volume has been examined from several aspects such as transaction level, data frequency, types of stocks, indices and futures. Although there are voluminous studies which have attempted to establish the empirical and theoretical structure of this relation, a consensus is yet to be reached (Saatcioglu \& Starks, 1998). Early studies, for example Granger and Morgenstern (1963) showed that price and volume are virtually unrelated and the price changes follow a random walk. Ying (1966) applied a series of Chi-squared tests, analysis of variance, and cross-spectral methods to a daily series of price and volume. He concluded that any models which separate prices from volumes will yield incomplete, if not erroneous results. Utilizing daily data, Crouch (1970) found positive correlations between absolute price changes and trading volumes for both market indices and individual stocks. Using stocks transaction data, Epps and Epps (1976) and Brailsford (1996) also found the same relationship among the variables. In addition, Lee and Rui (2002) found positive relationship between trading volume and stock market return in all the three markets of US, UK and Japan. However, Copeland (1976) showed no that there was relationship between stock return and trading volume in the domestic market. Gunduz and Hatemi-J (2005) investigated the causal relationship between stock prices and volume figures for stock markets in the Czech Republic, Hungary, Poland, Russia, and Turkey. Using the Toda-Yamamoto (1995) non-Granger causality tests, the results showed that there was no causal relationship between variables in the Czech Republic. In Hungary, there was a bidirectional causality irrespective of volume or the market turnover tested.
In Poland, while there was a bidirectional causality between stock prices and volume, there existed a unidirectional causality running from market turnover to stock prices. The stock prices influenced both volume and market turnover without any feedback in the case of Russia and Turkey.

Using monthly data from January 2003 to October 2006, Kamath (2008) also found that the trading volume influenced the stock prices in the Chilean stock market. In a more recent study, Mougoue (2010) examined the dynamic relationship between stock market trading volume and daily stock return for the Japanese stock market. Using both linear and nonlinear Granger causality, he found evidence that there existed linear Granger causality from return to trading volume, whereas there was non-linear Granger causality from trading volume to return.

In the context of Malaysia, Moosa and AlLoughani (1995) examined the price-volume relation in four Asian stock markets namely Malaysia, the Philippines, Singapore and Thailand. They found evidence for causality from volume to price changes and from price changes to volume. Mohamad and Nassir (1995) found absolute price changes have strong relationship with trading volume compared to price changes per se. However, causality tests indicated that price changes cause volume changes but not vice versa. In addition, Hameed and Ting (2000) examined the short-term predictability of stock returns and the level of trading activity in the Malaysian stock market. They found that the returns from a contrarian portfolio strategy are positively related to the level of trading activity in the securities. Thus, the contrarian profits on actively and frequently traded securities are significantly higher than low trading activity securities. 


\section{Empirical Approach and Data}

\section{Empirical Approach}

The study employs an autoregressive distributed lags (ARDL) bounds test proposed by Pesaran, Shin and Smith (2001) to investigate the cointegration relationship among the variables. The bounds testing procedure does not require the pre-testing of the unit roots of the variables included in the model unlike other techniques such as the Johansen and Juselius (1990) approach. More importantly, the bounds test procedure is simple. Pesaran and Shin (1995) showed that with the ARDL framework, the ordinary least squares estimators of the short-run parameters are consistent and the ARDL based estimators of the long-run coefficients are super-consistent in small sample sizes. Additionally, another advantage of the ARDL is the ARDL model takes sufficient number of lags to capture the data-generating process in a general-to-specific modelling framework. It estimates $(p+1)^{\mathrm{k}}$ number of regressions to obtain optimal lag-length for each variable, where $p$ is the maximum lag, and $k$ is the number of variables in the equation (Laurenceson \& Chai, 2003).

The error correction version of the ARDL model relating to the three variables incorporated in our study is stated as follows:

$$
\Delta F P_{t}=\alpha_{0}+\sum_{i=1}^{p} \lambda_{1 i} \Delta F P_{t-i}+\sum_{i=0}^{p} \lambda_{2 i} \Delta V O L_{t-i}
$$$$
+\sum_{i=0}^{p} \lambda_{3 i} \Delta S P_{t-i}+\delta_{1} F P_{t-1}+\delta_{2} V O L_{t-1}
$$$$
+\delta_{3} S P_{t-1}+\varepsilon_{t}
$$

where $\Delta$ is the difference operator; $F P, V O L$ and SP refer to futures price, trading volume and spot price index respectively; $\square_{t}$ is white noise error term. The following are steps to test the cointegration relationship among the variables. Firstly, we estimate Equation (1) by the ordinary least squares (OLS) technique. Pesaran et al. (2001) noted that the above model is based on the assumption that the error term $\square_{t}$ is serially uncorrelated. Thus, it is important that the lag order $p$ of the underlying model is chosen appropriately. We use appropriate lag length based on Akaike Information Criterion (AIC) (Akaike, 1974) with no serial correlation in the model.

Secondly, the presence of cointegration is traced by restricting all estimated coefficients of lagged level variables equal to zero. That is, the null hypothesis $\mathrm{H}_{0}: \delta_{1}=\delta_{2}=\delta_{3=} 0$ against the alternative, hypothesis $\mathrm{H}_{\mathrm{a}}: \delta_{1}$ $\square \delta_{2} \square \delta_{3} \square 0$. These hypotheses can be examined using the critical values bounds as tabulated in Pesaran et al. (2001). The relevant critical value bounds are based on case III with unrestricted intercepts and no trend and number of regressors, $k$ are 2 . If the computed $F$-statistics is less than the lower bound critical value, then we do not reject the null hypothesis of no cointegration. However, if the computed $F$-statistics is greater than the upper bound critical value, then we reject the null hypothesis and conclude that there exists a steady state equilibrium between the variables under study. However, if the computed value falls within the lower and the upper bound critical values, then the result is inclusive.

Having implemented cointegration tests, we proceed to specification and estimation of the Granger causality. In particular, the findings that the variables are non-stationary and are not cointegrated suggest the use of the Granger causality of VAR model in first differences. However, if they are cointegrated, a vector error correction model (VECM) or a level VAR can be used (Engle 
\& Granger, 1987). According to the Granger representation theorem, for any cointegrated series, error correction term must be included in the model. Engle and Granger (1987) and Toda and Phillips (1993) indicate that omitting this error correction term (ECT) in the model, leads to model misspecification. Through the ECT, the ECM opens up an additional channel for the Granger causality to emerge, that is completely ignored by the standard Granger and Sims tests (Masih \& Masih, 1999).

Utilizing VECM procedure permits us to make a distinction between the short- and long-run forms of the Granger-causality. The short-run causality is determined by the significance of the $F$-test or chi-square statistics of the differenced independent variables while the long-run causality is determined by the significance of $t$-test of the lagged ECT. The non-significance of both the $t$ and $F$-tests in the VECM indicates econometric exogeneity of the dependent variable (Masih \& Masih, 1999).

\section{Data Preliminaries}

This study uses daily data from January 2006 to August 2010 for the Kuala Lumpur Composite Index Futures (FKLI), FKLI trading volume and Kuala Lumpur Composite Index to represent spot price in Malaysia. All the data are extracted from the Datastream and transformed into logarithm.

\section{Table 1}

Descriptive Statistics of Futures and Spot Markets Returns and Percentage Change of Volume

\begin{tabular}{lccc}
\hline & $\Delta$ FP & $\Delta$ SP & $\Delta$ VOL \\
\hline Mean & 0.000413 & 0.000404 & 0.000598 \\
Maximum & 1.851265 & 0.198605 & 1.830712 \\
Minimum & -1.853596 & -0.192464 & -2.236445 \\
Std. Dev. & 0.148095 & 0.012494 & 0.432996 \\
Skewness & -0.129325 & -0.307433 & 0.013484 \\
Kurtosis & 111.9361 & 109.6823 & 4.080971 \\
Jarque-Bera & 570117.6 & 546786.2 & 56.17157 \\
Probability & 0.000000 & 0.000000 & 0.000000 \\
\hline
\end{tabular}

Table 2

Correlation of Futures Price, Spot Price and Volume

\begin{tabular}{cccc}
\hline & FP-SP & FP-VOL & SP-VOL \\
\hline Correlation & 0.83 & 0.20 & 0.25 \\
\hline
\end{tabular}


Table 1 presents the descriptive statistics of the data, including sample mean, maximum, minimum, standard deviations, skewness and kurtosis. Both futures and spot markets recorded positive average daily returns at $0.0413 \%$ and $0.0404 \%$ respectively. In terms of standard deviations, futures market recorded greater volatility compared to spot market. All market returns have excess kurtosis (greater than 3), which means that they have a thicker tail and a higher peak than a normal distribution. To highlight the short-run interactions between the variables, the results from the standard correlation of coefficient tests are given in Table 2. The results show that all the correlations are positive. We also note that the correlation of futures price-spot price is the highest.

\section{Empirical Findings}

\section{ARDL Cointegration Result}

- Before estimating the short- and long-run relationships among the variables, we have to decide on the lag-length on the first difference variables. Pesaran and Shin (1998) noted that the ARDL model requires a priori knowledge of the orders of the extended ARDL that is sufficient to correct simultaneously the residual serial correlation and the problem of endogenous regressors. In this study, the order of the distributed lag on the dependent variable and the regressors is selected using AIC with no serial correlation in the model. Based on AIC, the optimal lag-length is found to be four.

Turning to the result of the bound tests for cointegration, the computed F-statistics for testing the existence of a long-run relationship among the variables is $\mathrm{F}(\mathrm{FP} / \mathrm{VOL}, \mathrm{SP})=$ 27.42. The relevant critical value bounds are obtained from Pesaran et al. (2001), where the critical values in the case of two regressors are $3.79-4.85$ at the $5 \%$ significance level and $5.15-6.36$ at the $1 \%$ significance level. The results indicate that the null hypothesis of no cointegration can be rejected at $1 \%$ significance level (the F-statistics exceed the upper bound critical values). Thus, we find evidence of the existence of long-run relationship futures price, volume and spot prices. It further implies that the stock index futures markets are not efficient. Kasa (1992) noted that the existence of cointegration among the variables implies a common stochastic trend in those variables. Since each variable contains information on the common stochastic trends, the predictability of a series can be enhanced significantly by using information on the other variable. However, Dwyer and Wallace (1992) argued that there is no general equivalence between the existence of arbitrage opportunities and cointegration or, for that matter, a lack of cointegration. In addition, Lence and Falk (2005) provided evidence that the results of the tests of cointegration among asset prices have no implications about market efficiency or market integration without additional restrictions on the economy or economies.

Granger (1988) concludes that if there is a cointegration vector among the time series, there must be causality among these time series, at least in one direction. In order to examine the short-run dynamic linkages between the variables, the vector error correction model (VECM) is employed.

\section{VECM Causality Results}

According to the Granger representation theorem, for any cointegrated series, the error correction term must be included 
in the model. Engle and Granger (1987) and Toda and Phillips (1993) indicate that omitting this error correction term (ECT) in the model leads to model misspecification. Through the ECT, the ECM opens up an additional channel for the Granger-causality to emerge, that is completely ignored by the standard Granger and Sims tests (Masih \& Masih, 1999). To avoid misspecification in running the Granger causality, we also run the unit root tests of ADF and PP. To conserve space the results are not reported here. The unit root tests suggest that all data are stationary at first difference and thus indicating that all the variables are $I(1)$. The results of the VECM causality analysis are reported in Table 3. There seems to be short-run bidirectional causality relationship running between futures return-trading volume and futures return-spot return. The estimated coefficient for the error correction term is -0.12 , suggesting that the last period disequilibrium is corrected by 12 per cent on the following day. The results are in line with Hiemstra and Jones (1995), Moosa and AlLoughani (1995), Chordia and Swaminathan
(2000), Lee and Rui (2002) and Gunduz and Hatemi-J (2005) suggesting that there exists bidirectional causality running between return and volume. However, Saatcioglo and Starks (1998) argued that volume leads return, but not vice versa. In contrast, Bhagat and Bhatia (1996) provide evidence that price changes lead volume, but there is no evidence that volume leads price change. Thus, our results recognize that trading volume may provide important information on futures pricing. In line with Blume et al. (1994) traders can profit from using volume information in addition to historical price information in making projections about future price changes.

The existence of price discovery, market efficiency, and market stability associated with spot and futures markets continues as a prominent discussion among academics, practitioners and regulators (Pizzi, Economopoulos \& O’neill, 1998). Arshanapalli and Doukas (1997) found that the two markets were highly cointegrated particularly during October 1987. In addition,

Table 3

VECM Causality Tests

\begin{tabular}{|c|c|c|c|c|}
\hline \multirow{2}{*}{$\begin{array}{l}\text { Dependent } \\
\text { Variables }\end{array}$} & \multicolumn{3}{|c|}{ Independent Variables ( $\chi^{2}$ - statistic $)$} & \multirow{2}{*}{$\frac{\text { t-statistics }}{\mathrm{ECT}_{\mathrm{t}-1}}$} \\
\hline & $\Delta \mathrm{FP}$ & $\Delta \mathrm{VOL}$ & $\Delta \mathrm{SP}$ & \\
\hline$\Delta \mathrm{FP}$ & - & $\begin{array}{l}12.04^{*} \\
{[0.02]}\end{array}$ & $\begin{array}{l}16.21^{* *} \\
{[0.00]}\end{array}$ & $\begin{array}{c}-0.12 \\
(-2.14)^{*}\end{array}$ \\
\hline$\Delta \mathrm{VOL}$ & $\begin{array}{l}16.24^{* *} \\
{[0.00]}\end{array}$ & - & $\begin{array}{l}14.71^{* *} \\
{[0.00]}\end{array}$ & $\begin{array}{c}0.04 \\
(1.76)\end{array}$ \\
\hline$\Delta \mathrm{SP}$ & $\begin{array}{l}31.64^{* *} \\
{[0.00]}\end{array}$ & $\begin{array}{r}3.744 \\
{[0.44]}\end{array}$ & - & $\begin{array}{l}-0.08 \\
(-4.832)^{* *}\end{array}$ \\
\hline
\end{tabular}

Notes: [.] denotes to p-value and (.) denotes to t-statistics.

** and * denotes significance at $1 \%$ and $5 \%$ level respectively 
French (1986) noted that futures markets have two important social functions. First, they facilitate the transfer of price risk, and second, they provide forecasts of prices. In this study, we also found evidence of strong association between futures and spot markets in Malaysia.

\section{Conclusion}

This paper examines the relationship between the futures price and trading volume. We employed the ARDL cointegration test and the VECM causality tests to examine both the long- and short-run dynamic causality among the variables. The data utilized are the daily data of futures price, trading volume and spot price spanning from 2006 to 2009 .

The results indicate that the null hypothesis of no cointegration can be rejected at $1 \%$ significance level (the F-statistics exceed the upper bound critical values). Thus, we found evidence of the existence of long-run relationship of futures price, volume and spot prices. In addition, there seems to be a short-run bidirectional causality relationship running between futures return-trading volume and futures return-spot return. Therefore, this study provides evidence that price-volume relationship found in the equity market also exists within the futures market.

The findings that the variables are cointegrated suggest that each series contains information on the common stochastic trends, thus the predictability of one series can be enhanced considerably through utilizing information on the other series. Thus, this means that both the stock market and the futures market are informational inefficient since information in one market can be utilized to make predictions on the movement of the other markets.

\section{Acknowledgements}

This research is partly supported by the FundamentalResearchGrantScheme(FRGS), Grant No: FGRS/05(29)/783/2010(64).

\section{References}

Akaike, H. (1974). A new look at the statistics model identification. IEEE Transactions on Atomic Control AC, 19, 716-723.

Arshanapalli, B., \& Doukas. J. (1997). The linkages of S\&P 500 stock index and S\&P 500 stock index futures prices during October 1987. Journal of Economics and Business, 49(3), 253-266.

Bacha, O. I. (2006). Financial derivatives: Markets and applications in Malaysia. Kuala Lumpur: McGraw Hill.

Bhagat, S., \& Bhatia, S. (1996). Trading volume and price variability: Evidence on lead-lag relations from Granger-causality tests. Working Paper, University of Colorado at Boulder.

Bessembinder, H., \& Segun, P. J. (1995). Futures-trading activity and stock price volatility. The Journal of Finance, 47(5), 2015-2034.

Blume, E., Easley, D., \& O’hara, M. (1994). Market statistics and technical analysis: The role of volume. Journal of Finance, 49, 153-181.

Brailsford, T. J. (1996). The empirical relationship between trading volume, returns, and volatility. Accounting and Finance, 36(1), 89-111.

Bursa Malaysia Derivatives Berhad. (2010). Bursa Malaysia Derivatives Berhad (Annual Report). Kuala Lumpur. 
Chordia, T., \& Swaminathan, B. (2000). Trading volume and crossautocorrelations in stock returns. The Journal of Finance, 55 (2), 913-935.

Clark,P. K. (1973). A subordinated stochastic process model with finite variance for speculative prices. Econometrica, 4l(1), 135-155.

Copeland, T. E. (1976). A model of asset trading under the assumption of sequential information arrival. Journal of Finance, 31, 1149-1168.

Crouch, R. (1970). The volume of transaction and price changes on the New York Stock Exchange. Financial Analysts Journal, 26(4),104-109.

Dwyer, G. P., \& Wallace, M. S. (1992) Cointegration and market efficiency. Journal of International Money and Finance, 11(4), 318-327.

Engle, R. F., \& Granger, C. W. J. (1987). Cointegration and error correction: Representation, estimation, and testing, Econometrica, 55, 251-276.

Epps, T. W., \& Epps, M. L. (1976). The stochastic dependence of security price changes and transaction volumes: Implications for the mixture-of-distributions hypothesis. Econometrica, 44(2), 305-321.

French, K. R. (1986). Detecting spot price forecasts in futures prices. The Journal of Business, 59(2), 39-54.

Granger, C. W. J. (1988). Some recent developments in a concept of causality. Journal of Econometrics, 39, 199-211.

Granger, C. W. J., \& Morgenstern, O. (1963). Spectral analysis of New York stock market prices. Kyklos, 16(1), 1-27.

Gunduz, L., \& Hatemi-J, A. N. (2005). Stock price and volume relation in emerging markets. Emerging Markets Finance and Trade, 41(1), 29-44.
Hameed, A., \& Ting, S. (2000). Trading volume and short-horizon contrarian profits: Evidence from the Malaysian market. Pacific-Basin Finance Journal, 8, 67-84.

Hiemstra, C., \& Jones, J. D. (1995). Testing for linear and non-linear Granger causality in the stock price-volume relation. Journal of Finance, 49, 1639-1664.

Johansen, J., \& Juselius, K. (1990). Maximum likelihood estimation and inference on cointegration with applications to the demand for money. Oxford Bulletin of Economics and Statistics, $52,169-210$.

Kamath, R. R. (2009). The price-volume relationship in the Chilean stock market. International Business \& Economics Research Journal, 7(10), 7-14.

Karpoff, J. M. (1987). The relation between price changes and trading volume: A survey. Journal of Financial and Quantitative Analysis, 22(1), 109126.

Kasa, K. (1992). Common stochastic trends in international stock markets. Journal of Monetary Economics, 29, 95-124.

Laurenceson, J., \& Chai, J. C. H. (2003). Financial reform and economic development in China. Cheltenham, UK: Edward Elgar.

Lee, B. S., \& Rui, O. M. (2002). The dynamic relationship between stock returns and trading volume: Domestic and cross-country evidence. Journal of Banking and Finance, 26, 51-78.

Lence, S., \& Falk, B. (2005). Cointegration, market integration, and market efficiency. Journal of International Money and Finance, 24(6), 873890. 
Long, D. M. (2007). An examination of the price-volume relationship in the option markets. International Research Journal of Finance and Economics, 10, 47-56.

Masih, A. M. M., \& Masih, R. (1999). Are Asian stock market fluctuations due mainly to intra-regional contagion effects? Evidence based on Asian emerging stock markets. PacificBasin Finance Journal, 7, 251-82.

Mohamad, S., \& Nassir, A. M. (1995). Price changes and trading volume relationship: Some preliminary evidence from the Kuala Lumpur Stock Exchange. Pertanika Journal of Social Sciences and Humanities, 3(2), 147-154.

Moosa, I. A., \& Al-Loughani, A. E. (1995). Testing the price-volume relation in emerging Asian stock markets. Journal of Asian economics, 6(3), 407-422.

Mougoue, M. (2010). A dynamic analysis of the volume-return relationship in the Japanese stock market. Department of Finance, Wayne State University.

Pesaran, M. H., \& Shin, Y. (1995). An autoregressive distributed lag modeling approach to cointegration analysis. DAE Working Paper No. 9514, Department of Applied Economics, University of Cambridge.
Pesaran,M.H.,\& Shin,Y.(1998). Generalised impulse response analysis in linear multivariate models. Economics Letters, 58, 17-29.

Pesaran, M. H., Shin, Y., \& Smith, R. J. (2001). Bound testing approaches to the analysis of level relationship. Journal of Applied Econometrics, 16, 289-326.

Pizzi,M.A.,Economopoulos,A.J.,\& O'neill, H. M. (1998). An examinations of the relationship between stock index cash and futures markets: A cointegration approach. Journal of Futures Markets, 18(3), 297-305.

Saatcioglu, K., \& Starks, L. T. (1998). The stock price-volume relationship in emerging stock markets: The case of Latin America. International Journal of Forecasting, 14(2), 215-225.

Tauchen, G.E., \& Pitts, M. (1983). The price volatility-volume relationship on speculative markets. Econometrica, 51(2), 485-505.

Toda, H. Y., \& Phillips, P.C. B. (1993). Vector auto-regressions and causality. Econometrica, 61, 1367-1393.

Toda, H. Y., \& Yamamoto, T. (1995). Statistical inference in vector autoregressions with possibly integrated processes. Journal of Econometrics, 66(1), 225-250.

Ying, C. C. (1966). Stock market prices and volumes of sales. Econometrica, 34(3), 676-685. 